\title{
Factors Affecting the Incidence of Uncontrolled Hypertension in Patients Performing Routine Examinations at the Kebayakan Public Health Center, Central Aceh Regency
}

\author{
Thomson P. Nadapdap ${ }^{1}$, Zuraidah Nasution ${ }^{1}$, Indra Wahyudi ${ }^{1}$ \\ ${ }^{1}$ Master of Public Health Study Program, Helvetia Health Institute, Medan, Indonesia
}

\begin{abstract}
The purpose of the study was to determine the factors that influence the incidence of uncontrolled hypertension in patients who carry out routine checks at the Community Health Center (Puskesmas). Method: using analytical survey method using Case Control research design. The sample was 148 respondents, 74 case groups and 74 control groups were taken by purposive sampling. Data analysis was performed univariate, bivariate and multivariate with multiple logistic regression. The results of the bivariate test showed that the factors influencing the incidence of uncontrolled hypertension were age $(\mathrm{p}=0.002$; OR $=3,253)$, family history $(\mathrm{p}=0.000 ; \mathrm{OR}=4.216)$, obesity $(\mathrm{p}=0.005 ; \mathrm{OR}=2.734)$, physical activity $(\mathrm{p}=0.000 ; \mathrm{OR}=$ 4.229), salt consumption ( $\mathrm{p}=0.000$; $\mathrm{OR}=4,127)$, coffee consumption ( $\mathrm{p}=0.010$; $\mathrm{OR}=4,127)$, stress $(\mathrm{p}=0.000 ; \mathrm{OR}=3,745)$, medication adherence $(\mathrm{p}=0.000 ; \mathrm{OR}=4.492)$. Factors that were not related were gender $(\mathrm{p}=0.620 ; \mathrm{OR}=0.803)$, smoking $(\mathrm{p}=1,000 ; \mathrm{OR}=1,000)$. While the results of the multivariate test showed that the most influential factors with the incidence of uncontrolled hypertension were medication adherence variable $(\mathrm{p}=0.000 ; \operatorname{Exp}(\mathrm{B})=5.982)$, and obesity variable $(\mathrm{p}=0.002 ; \operatorname{Exp}(\mathrm{B})=4.945)$. In conclusion, the dominant factors that influence the incidence of uncontrolled hypertension at the Kebayakan Health Center are medication adherence and obesity.
\end{abstract}

Keywords: Uncontrolled Hypertension, Medication Adherence, Obesity

Received: November 17, 2021

Received in Revised: December 15, 2021

Accepted: December 26, 2021

\section{Introduction}

Non-communicable illnesses are now the leading cause of mortality in the world, according to the World Health Organization. Non-communicable disease epidemics claim the lives of 17 million people each year. There's a good chance that this percentage will rise to 29\% by 2025 . The remaining 333 individuals with hypertension live in affluent nations, with 639 million living in underdeveloped countries, including Indonesia (Windarsih \& Devianto, 2017).

A Triple Burden is being placed on Indonesia's health sector as infectious illnesses remain a public health issue, while morbidity and death rates from NCDs (Non-Communicable Diseases) continue to rise, and at the same time confront the problems of re-emerging or recurrent diseases.. a rise in the number of illnesses. Changes in the environment, community behavior, demographic transition, socio-economic and socio-cultural factors have a significant impact on illness patterns (Dinkes, 2018).

Hypertension is a widespread cardiovascular condition that affects millions of people throughout the globe, not only in Indonesia. In 2015, the WHO estimated that 1.13 billion individuals throughout the globe have hypertension, making it the third most common disease in the world. By 2025, there are expected to be 1.5 billion individuals with hypertension, and 9.4 million people die each year from hypertension and its sequelae. 
Increased adherence to pharmacological and non-pharmacological treatment is necessary for patients with uncontrolled hypertension to reach normal blood pressure. An unhealthy lifestyle, excessive salt intake, and non-adherence to antihypertensive medication may cause an elevation in blood pressure. As a result, in order to prevent mortality, morbidity, and complications, patients with uncontrolled hypertension must be aware of the risk factors for such hypertension.

The prevalence of hypertension continues to increase from year to year, so we need a strategy that can help officers and the public to be able to find out as early as possible the tendency of hypertension. The development of comprehensive services should be carried out since primary care, in this case the puskesmas. Puskesmas as the spearhead of effective and integrated hypertension services (Depkes, 2003).

The results of the initial data search conducted by researchers found cases of hypertension at the Kebayakan Health Center, Central Aceh Regency, which showed a significant increase, recorded from 2019 hypertension as many as 1,333 cases, then in 2020 an increase of 1,684 cases who did not regularly visit the Kebayakan Health Center and there were no records Referral Program (PRB) from the Regional General Hospital. When compared with the 2019 national prevalence data, which is $34.11 \%$ and the Central Aceh District prevalence data, which is $32.8 \%$, it can be seen that the prevalence of hypertension at the Kebayakan Health Center is quite high

\section{Methods}

The type of research used in this research is an analytical survey research method using a Case Control research design. Data was collected by comparing the incidence of the case group and the control group based on exposure to risk factors (Notoatmodjo, 2010). The population in this study is a large number of subjects who have certain characteristics (Low, 2011). The population in this study was 1,684 cases. The number of case samples was 74 people and the control sample was 74 people, so the total research subjects were 148 people taken by purposive sampling

\section{Results and Discussion}

\section{Univariate Analysis}

Table 1. Frequency Distribution Based on Characteristics of Respondents with Hypertension Incidence at the Kebayakan Health Center, Central Aceh Regency in 2021

\begin{tabular}{|c|c|c|c|c|c|}
\hline \multirow{3}{*}{ Variable } & \multicolumn{4}{|c|}{ Incidence of Hypertension } & \multirow{3}{*}{ Sum } \\
\hline & \multicolumn{2}{|c|}{ Case } & \multicolumn{2}{|c|}{ Control } & \\
\hline & $\mathbf{F}$ & $\%$ & $\mathbf{f}$ & $\%$ & \\
\hline Age & & & & & \\
\hline 18-59 years old & 35 & 23,6 & 16 & 10,8 & 51 \\
\hline$\geq 60$ years & 39 & 26,4 & 58 & 39,2 & 97 \\
\hline Gender & & & & & \\
\hline Man & 31 & 20,9 & 35 & 23,6 & 66 \\
\hline Woman & 43 & 29,1 & 39 & 26,4 & 82 \\
\hline Family History & & & & & \\
\hline Ada & 59 & 39,9 & 34 & 23,0 & 93 \\
\hline Tidak Ada & 15 & 10,1 & 40 & 27,0 & 55 \\
\hline
\end{tabular}




\begin{tabular}{|l|c|c|c|c|c|}
\hline Obesity & 42 & 28,4 & 24 & 16,2 & 66 \\
Normal & 32 & 21,6 & 50 & 33,8 & 82 \\
\hline Obesity & & & & & \\
No smoking & 55 & 37,2 & 55 & 37,2 & 110 \\
Smoke & 19 & 12,8 & 19 & 12,8 & 38 \\
\hline Physical Activity & & & & & \\
Good & 26 & 17,6 & 52 & 35,1 & 78 \\
Less & 48 & 32,4 & 22 & 14,9 & 70 \\
\hline Salt Consumption & & & & & \\
Good & 21 & 14,2 & 56 & 37,8 & 77 \\
More & 53 & 35,8 & 18 & 12,2 & 71 \\
\hline Coffee Consumption & & & & & \\
Often & 39 & 26,4 & 55 & 37,2 & 94 \\
Infrequently & 35 & 23,6 & 19 & 12,8 & 54 \\
\hline Stress & & & & & \\
Stress & 43 & 29,1 & 20 & 13,5 & 63 \\
Normal & 31 & 20,9 & 54 & 36,5 & 85 \\
\hline Drug Consumption & & & & & \\
Compliance & 45 & 30,4 & 19 & 12,8 & 64 \\
Disobedient & 29 & 19,6 & 55 & 37,2 & 84 \\
Obedient & & & & & \\
\hline
\end{tabular}

For the purposes of this research, participants were divided into two age ranges: 18-59 and 60+. Table 1 reveals that 65.54 percent (97 persons) of respondents in the case and control groups are above the age of 60 . Table 1 demonstrates that the case and control groups had a higher percentage of female respondents, with 43 respondents $(29.1 \%)$ in the case group and 39 respondents in the control group (26.4 percent).

In the case group, there were 59 persons with family history (39\%), whereas in the control group, there were up to 34 people with family history (23.0 percent). Obesity prevalence in the control group was 33.8 percent, while 32 persons in the case group were obese ( 21.6 percent).

Smoking behaviors in both the case and control groups were found to be the same at every level of data processing. More over half of the participants in both the control group and the case group were non-smokers, according to the statistics.

Physical activity may be split into two categories, as shown in table 1: inadequate physical activity and excellent physical activity. More over one third (32.4 percent) of those surveyed in both the case group and the control group reported that they were not physically active (14.9 percent).

Salt consumption in the case group was found to be 35.8 percent greater than in the control group, a difference of 53. (12.2 percent). There were 37.8\% more participants in the control group (56 people) than in the case group ( 21 people) who had adequate salt consumption (14.2 percent).

Table 1 shows that coffee drinkers fall into two categories: those who drink it often and those who don't drink it at all. There were 39 persons in the case group who were classified as regular coffee drinkers, and there were 55 people in the control group who were classified as frequent coffee drinkers (37.2 percent). In the case group, there were 43 persons $(29.1 \%)$ with high 
levels of stress, whereas in the control group, there were 20 people (control group) (13.5 percent). In the non-adherent group, there were 45 persons (or $30.4 \%$ of the total), whereas in the control group, there were 19 people (or $0.9 \%$ of the total) (12.8 percent).

\section{Bivariate Analysis}

\section{Influence of age with the incidence of hypertension}

Table 2. Results of Bivariate Analysis between age and the incidence of hypertension at the Kebayakan Health Center, Central Aceh Regency in 2021

\begin{tabular}{|c|c|c|c|c|c|c|c|}
\hline \multirow[b]{3}{*}{ Age } & \multicolumn{4}{|c|}{ Incidence of Hypertension } & \multirow{3}{*}{ Sum } & \multirow{3}{*}{$p$} & \multirow{3}{*}{$\begin{array}{c}\text { OR } \\
\text { CI } 95 \%\end{array}$} \\
\hline & \multicolumn{2}{|c|}{ Case } & \multicolumn{2}{|c|}{ Control } & & & \\
\hline & $\mathbf{F}$ & $\%$ & & $\%$ & & & \\
\hline 18-59 years old & 35 & 47,3 & 16 & 21,6 & 51 & 0,002 & 3,253 \\
\hline$\geq 60$ years & 39 & 52,7 & 58 & 78,4 & 97 & & $(1,588-6,666)$ \\
\hline Total & 74 & 100 & 74 & 100 & 148 & & \\
\hline
\end{tabular}

As a result of the examination of the impact of age on the occurrence of hypertension, it can be concluded that the age group of 18-59 years in the case group is greater than the 35 persons in the control group (47.3 percent). 60 -year-olds comprised more of the control group than the 58 in the study's case group (78.4 percent). Hypertension is more likely to occur in those who are older, according to the findings of statistical analyses, with a significance test value of 0.002 (0.05).

To put it another way, people who are 60 years old or older have a three-fold increased likelihood of developing hypertension than those who are 18 to 59 years old.

\section{Influence of sex with the incidence of hypertension}

Table 3. Results of Bivariate Analysis between the sexes with the incidence of hypertension in Central Aceh Regency Health Center in 2021

\begin{tabular}{|c|c|c|c|c|c|c|c|}
\hline \multirow[b]{3}{*}{ Gender } & \multicolumn{4}{|c|}{ Incidence of Hypertension } & \multirow{3}{*}{ Sum } & \multirow{3}{*}{$p$} & \multirow{3}{*}{$\begin{array}{c}\text { OR } \\
\text { CI 95\% }\end{array}$} \\
\hline & \multicolumn{2}{|c|}{ Case } & \multicolumn{2}{|c|}{ Control } & & & \\
\hline & $\mathbf{F}$ & $\%$ & $\mathbf{f}$ & $\%$ & & & \\
\hline Man & 31 & 41,9 & 35 & 47,3 & 66 & 0,620 & 0,803 \\
\hline Woman & 43 & 58,1 & 39 & 52,7 & 82 & & $(0,420-1,538)$ \\
\hline Total & 74 & 100 & 74 & 100 & 148 & & \\
\hline
\end{tabular}

It is possible to infer from the findings of the analysis of gender and the incidence of hypertension that there are more women in the case group than in the control group, with a total of 43 persons in the case group compared to the control group (58.1 percent). While there were more men in the control group than there were in the case group, there were 35 men in the control group (47.3 percent). After statistical analyses were performed, the findings revealed a significant test value of $0.620(>0.05)$ for the presence of gender differences in the incidence of hypertension. Therefore, it is concluded that there is no association between gender and the incidence of hypertension.

\section{Effect of family history with the incidence of hypertension}

Table 4. Results of Bivariate Analysis between family history and the incidence of hypertension at the Kebayakan Health Center, Central Aceh Regency in 2021

\begin{tabular}{|l|l|l|l|l|}
\hline & Incidence of Hypertension & & & OR \\
\hline
\end{tabular}




\begin{tabular}{|c|c|c|c|c|c|c|c|}
\hline \multirow[t]{2}{*}{ Family History } & \multicolumn{2}{|c|}{ Case } & \multicolumn{2}{|c|}{ Control } & \multirow[t]{2}{*}{ Sum } & \multirow[t]{2}{*}{$p$} & \multirow[t]{2}{*}{ CI 95\% } \\
\hline & $\mathbf{f}$ & $\%$ & $\mathbf{F}$ & $\%$ & & & \\
\hline Unavailable & 15 & 20,3 & 40 & 54,1 & 55 & 0,000 & 4,216 \\
\hline Available & 59 & 79,7 & 34 & 45,9 & 93 & & $(1,104-5,448)$ \\
\hline Total & 74 & 100 & 74 & 100 & 148 & & \\
\hline
\end{tabular}

Table 4 shows that there were more persons in the case group who had a family history of hypertension than in the control group, specifically 59 people, as compared to the control group (79.7 percent). The results of the statistical analyses revealed that there was a statistically significant relationship between the incidence of hypertension and family history, with a significance value of 0.000 ( $\mathrm{p}$ 0.05) between the two variables examined.

According to the findings of the analysis, the odds ratio (OR) of 4.216 (95 percent confidence interval: 1.104-5.448) indicates that respondents who have a family history of hypertension have a fourfold increased risk of developing hypertension when compared to respondents who do not have a family history.

\section{The effect of obesity with the incidence of hypertension}

Table 5. Results of Bivariate Analysis between obesity and the incidence of hypertension at the Kebayakan Health Center, Central Aceh Regency in 2021

\begin{tabular}{|c|c|c|c|c|c|c|c|}
\hline \multirow{2}{*}{ Obesity } & \multicolumn{3}{|c|}{ Incidence of Hypertension } & \multirow{2}{*}{ Control } & \multirow{2}{*}{ Sum } & \multirow{P}{*}{$\begin{array}{c}\text { OR } \\
\text { CI 95\% }\end{array}$} \\
\cline { 2 - 5 } & \multicolumn{2}{|c|}{ Case } & \multicolumn{2}{c|}{ Contron } & & \\
\hline Normal & 42 & 56,8 & 24 & 32,4 & 66 & 0,005 & 2,734 \\
Obesity & 32 & 43,2 & 50 & 67,6 & 82 & & $(1,400-5,342)$ \\
\hline Total & 74 & 100 & 74 & 100 & 148 & & \\
\hline
\end{tabular}

In table 5. it can be seen that in the control group there are more obese people with controlled hypertension than the case group, namely 50 people $(67.6 \%)$. The statistical test results show that there is a significant effect between the incidence of hypertension and obesity with a significant value. of $0.005(\mathrm{p}<0.05)$.

In the analysis results, the value of $\mathrm{OR}=2.734$ (95\% CI: $1.400-5.342)$ means that respondents who have obesity with hypertension have 2 times more chance of having hypertension than respondents who are not obese.

\section{The effect of smoking with the incidence of hypertension}

Table 6. Results of Bivariate Analysis between smoking and the incidence of hypertension at the Kebayakan Health Center, Central Aceh Regency in 2021

\begin{tabular}{|c|c|c|c|c|c|c|c|}
\hline \multirow{2}{*}{ Smoke } & \multicolumn{3}{|c|}{ Incidence of Hypertension } & \multirow{3}{*}{ Sum } & \multirow{2}{*}{$\boldsymbol{P}$} & OR \\
\cline { 2 - 5 } & \multicolumn{2}{|c|}{ Case } & \multicolumn{2}{c|}{ Control } & S5\% \\
\cline { 2 - 5 } & F & \% & f & \% & & & \\
\hline Not smoking & 55 & 74,3 & 55 & 74,3 & 110 & 1,000 & 1,000 \\
smoking & 19 & 25,7 & 19 & 25,7 & 38 & & $(0,478-2,091)$ \\
\hline Total & 74 & 100 & 74 & 100 & 148 & & \\
\hline
\end{tabular}

In table 6, it can be seen that the respondents who did not smoke in the case group were 33 people $(86.8 \%)$ and in the control group there were 55 people $(74.3 \%)$. In the control group who did not smoke with hypertension as much as the case group, namely 55 people $(74.3 \%)$. The results of statistical tests showed that there was no influence between smoking habits and 
the incidence of hypertension with a significance value of $1,000(\mathrm{p}>0.05)$. In the results of the analysis, the value of OR $=1,000$ (95\% CI: 0.478-2.091).

\section{Effect of physical activity with the incidence of hypertension}

Table 7. Results of Bivariate Analysis between physical activity and the incidence of hypertension at the Kebayakan Health Center, Central Aceh Regency in 2021

\begin{tabular}{|c|c|c|c|c|c|c|c|}
\hline \multirow{3}{*}{$\begin{array}{l}\text { Physical } \\
\text { Activity }\end{array}$} & \multicolumn{4}{|c|}{ Incidence of Hypertension } & \multirow{3}{*}{ Sum } & \multirow{3}{*}{$P$} & \multirow{3}{*}{$\begin{array}{c}\text { OR } \\
\text { CI } 95 \%\end{array}$} \\
\hline & \multicolumn{2}{|c|}{ Case } & \multicolumn{2}{|c|}{ Control } & & & \\
\hline & $\mathbf{f}$ & $\%$ & f & $\%$ & & & \\
\hline Good & 26 & 35,1 & 52 & 70,3 & 78 & 0,000 & 4,229 \\
\hline Less & 48 & 64,9 & 22 & 29,7 & 70 & & $(1,115-6,457)$ \\
\hline Total & 74 & 100 & 74 & 100 & 148 & & \\
\hline
\end{tabular}

In table 7 it can be seen that respondents with good physical activity in the case group were 26 people (35.1\%) and in the control group were 52 people $(70.3 \%)$. In the case group with less physical activity who experienced uncontrolled hypertension, hypertension was more than the case group, which was 48 people (64.9\%). The results of statistical tests showed that there was a significant effect between the incidence of hypertension and physical activity with a significance value of $0.000(\mathrm{p}<0.05)$.

In the analysis results, the value of $\mathrm{OR}=4.229$ (95\% CI: $1.115-6.457)$ means that respondents with less physical activity have a 4 times greater chance of experiencing hypertension than respondents with less physical activity.

\section{Effect of salt consumption with the incidence of hypertension}

Table 8. Results of Bivariate Analysis between physical salt consumption and the incidence of hypertension at the Kebayakan Health Center, Central Aceh Regency in 2021

\begin{tabular}{|c|c|c|c|c|c|c|c|}
\hline \multirow{3}{*}{$\begin{array}{c}\text { Salt } \\
\text { Consumption }\end{array}$} & \multicolumn{4}{|c|}{ Incidence of Hypertension } & \multirow{3}{*}{ Sum } & \multirow{3}{*}{$\boldsymbol{P}$} & \multirow{3}{*}{$\begin{array}{c}\text { OR } \\
\text { CI 95\% }\end{array}$} \\
\hline & \multicolumn{2}{|c|}{ Case } & \multicolumn{2}{|c|}{ Control } & & & \\
\hline & $\mathbf{f}$ & $\%$ & f & $\%$ & & & \\
\hline Good & 21 & 75,7 & 56 & 52,0 & 77 & 0,000 & 4,127 \\
\hline More & 53 & 24,3 & 18 & 48,0 & 71 & & $(1,012-6,265)$ \\
\hline Total & 74 & 100 & 74 & 100 & 148 & & \\
\hline
\end{tabular}

The results of statistical tests showed that the proportion of respondents with good salt intake was more in the control group than the case group, namely 56 people $(52.0 \%)$. While the proportion of salt intake that was more in the case group than the control group was 53 people $(24.3 \%)$. Based on the test results, it is known that there is an influence between salt intake and the incidence of hypertension with a p-value of $0.000(\mathrm{p}<0.05)$. From the results of the analysis, the $\mathrm{OR}=4.127$ (95\% CI: 1.012-6.265) means that respondents with excessive salt intake have a 4 times greater risk of developing hypertension.

\section{The effect of coffee consumption with the incidence of hypertension}

Table 9. Results of Bivariate Analysis between coffee consumption and the incidence of hypertension at the Kebayakan Health Center, Central Aceh Regency in 2021

\begin{tabular}{|c|c|c|c|c|c|c|c|}
\hline \multirow{3}{*}{$\begin{array}{c}\text { Coffee } \\
\text { Consumption }\end{array}$} & \multicolumn{4}{|c|}{ Incidence of Hypertension } & \multirow{3}{*}{ Sum } & \multirow{3}{*}{$\boldsymbol{P}$} & \multirow{3}{*}{$\begin{array}{c}\text { OR } \\
\text { CI 95\% }\end{array}$} \\
\hline & & & & & & & \\
\hline & $\mathbf{f}$ & $\%$ & $\mathbf{f}$ & $\%$ & & & \\
\hline
\end{tabular}




\begin{tabular}{|l|c|c|c|c|c|c|c|}
\hline Often & 39 & 52,7 & 55 & 74,3 & 94 & 0,010 & 4,127 \\
Infrequently & 35 & 47,3 & 19 & 25,7 & 54 & & $(1,012-6,265)$ \\
\hline Total & 74 & 100 & 74 & 100 & 148 & & \\
\hline
\end{tabular}

The results of statistical tests showed that the proportion of respondents with frequent good coffee consumption was more in the control group than the case group, which was 55 people (74.3\%). Meanwhile, the proportion of coffee consumption that was rarely good was more in the case group than the control group, namely 35 people $(47.3 \%)$. Based on the results of the tests conducted, it is known that there is an effect between coffee consumption and the incidence of hypertension with a p-value of $0.010(\mathrm{p}<0.05)$.

From the results of the analysis, the OR $=2.276$ (95\% CI: 1.192-3.770) means that respondents with frequent coffee consumption have a 2 times greater risk of developing hypertension than respondents with infrequent coffee consumption.

\section{The effect of stress with the incidence of hypertension}

Table 10. Results of Bivariate Analysis between stress and the incidence of hypertension at the Kebayakan Health Center, Central Aceh Regency in 2021

\begin{tabular}{|c|c|c|c|c|c|c|c|}
\hline \multirow{2}{*}{ Stress } & \multicolumn{3}{|c|}{ Incidence of Hypertension } & \multirow{2}{*}{ Sum } & \multirow{2}{*}{$\boldsymbol{P}$} & OR \\
\cline { 2 - 5 } & \multicolumn{2}{|c|}{ Case } & \multicolumn{2}{c|}{ Control } & & CI 95\% \\
\cline { 2 - 5 } & f & \% & f & \% & & & 3,745 \\
\hline Stress & 43 & 58,1 & 20 & 27,0 & 63 & 0,000 & $(1,878-7,469)$ \\
\hline Normal & 31 & 41,9 & 54 & 73,0 & 85 & & \\
\hline Total & 74 & 100 & 74 & 100 & 148 & & \\
\hline
\end{tabular}

The results of statistical tests showed that the proportion of normal respondents was more in the control group than the case group, namely 54 people $(73.0 \%)$. Meanwhile, the proportion of respondents who experienced stress was more in the case group than the control group, namely 43 people $(58.1 \%)$. Based on the results of the tests conducted, it is known that there is an influence between stress and the incidence of hypertension with a p-value of 0.000 $(\mathrm{p}<0.05)$.

From the results of the analysis, it was also obtained that the OR $=3.745$ (95\% CI: 1.878 7.469) means that respondents with the stress category have a 3 times greater risk of experiencing hypertension than respondents with respondents who experience stress.

\section{The effect of drug consumption compliance with the incidence of hypertension}

Table 11. Results of Bivariate Analysis between drug consumption compliance with the incidence of hypertension at the Kebayakan Health Center, Central Aceh Regency in 2021

\begin{tabular}{|c|c|c|c|c|c|c|c|}
\hline \multirow{3}{*}{$\begin{array}{c}\text { Drug } \\
\text { Consumption } \\
\text { Compliance }\end{array}$} & \multicolumn{4}{|c|}{ Incidence of Hypertension } & \multirow{3}{*}{ Sum } & \multirow{3}{*}{$\boldsymbol{P}$} & \multirow{3}{*}{$\begin{array}{c}\text { OR } \\
\text { CI } 95 \%\end{array}$} \\
\hline & \multicolumn{2}{|c|}{ Case } & \multicolumn{2}{|c|}{ Control } & & & \\
\hline & $\mathbf{f}$ & $\%$ & $\mathbf{f}$ & $\%$ & & & \\
\hline Disobedient & 45 & 60,8 & 19 & 25,7 & 64 & 0,000 & ,492 (2,231- \\
\hline Obedient & 29 & 39,2 & 55 & 74,3 & 84 & & $9,045)$ \\
\hline Total & 74 & 100 & 74 & 100 & 148 & & \\
\hline
\end{tabular}

The results of statistical tests showed that the proportion of respondents with adherence to drug consumption was more in the control group than the case group, namely 55 people $(74.3 \%)$. Meanwhile, the proportion of respondents who did not comply was more in the case group than the control group, namely 45 people $(60.8 \%)$. Based on the results of the tests conducted, it is 
known that there is an influence between drug consumption compliance with the incidence of hypertension with a p-value of $0.000(\mathrm{p}<0.05)$.

From the results of the analysis, the OR $=4.492$ (95\% CI: 2.231-9.045) means that respondents with drug consumption compliance have a 3 times greater risk of experiencing hypertension than respondents who do not adhere to taking drugs.

\section{Multivariate Analysis}

Table 12. Select of Variables That Are Model Candidates in Multiple Logistic Regression Tests Based on Bivariate Analysis

\begin{tabular}{|l|c|r|r|r|r|}
\hline \multicolumn{1}{|c|}{ Variable } & \multicolumn{1}{c|}{ B } & \multicolumn{1}{c|}{ S.E. } & \multicolumn{1}{c|}{ Itself } & \multicolumn{1}{c|}{$\operatorname{Exp(B)}$} & \multicolumn{1}{c|}{ 95\% CI } \\
\hline Age & 1,138 &, 580 &, 050 & 3,120 & $1,001-9,725$ \\
\hline Descendants & 1,519 &, 523 &, 004 &, 219 & $, 079-0,610$ \\
\hline Obesity & 1,487 &, 539 &, 006 & 4,423 & $1,538-12,716$ \\
\hline Activities & 0,513 &, 563 &, 362 &, 599 & $, 199-1,805$ \\
\hline Salt & 1,438 &, 524 &, 001 &, 087 & $, 031-0,244$ \\
\hline Coffee & 0,301 &, 625 &, 631 &, 740 & $, 217-2,521$ \\
\hline Stress & 1,447 &, 543 &, 008 & 4,252 & $1,467-12,320$ \\
\hline Compliance & 2,753 &, 518 &, 000 & 5,772 & $2,091-15,930$ \\
\hline
\end{tabular}

Based on the table above, it shows that the eight variables studied were used as model candidates in multiple logistic regression because they had a significant value of $<0.25$. Variables that were excluded were gender and smoking variables because they had sig values $>0.25$.

Further testing was carried out simultaneously with the forward conditional method to identify the most influential factors on the incidence of uncontrolled hypertension in patients undergoing routine examinations.

Table 13. Multiple Logistic Regression Test Results

\begin{tabular}{|c|c|c|r|r|r|}
\hline Variable & \multicolumn{1}{|c|}{ B } & \multicolumn{1}{c|}{ S.E. } & \multicolumn{1}{c|}{ Itself } & $\operatorname{Exp(B)}$ & \multicolumn{1}{c|}{ 95\%CI } \\
\hline Age & 1,367 & 0,515 &, 008 & 3,924 & $1,429-10,775$ \\
\hline Descendants & 1,582 & 0,517 &, 002 & 0,206 & $0,075-0,566$ \\
\hline Obesity & 1,598 & 0,521 &, 002 & 4,945 & $1,782-13,720$ \\
\hline Salt & 1,514 & 0,520 &, 000 & 0,081 & $0,029-0,225$ \\
\hline Stress & 1,547 & 0,506 &, 002 & 4,696 & $1,740-12,673$ \\
\hline Compliance & 2,789 & 0,513 &, 000 & 5,982 & $2,189-16,345$ \\
\hline
\end{tabular}

After doing multiple logistic regression tests, a significant value was found at 0.0000 .05 , which indicates that the six factors included as models in this research had a statistically significant impact on the occurrence of uncontrolled hypertension in patients who received regular exams.

The factors of medication use compliance and obesity are the ones that have the most effect in this research, according to the findings. The variable of adherence to medication consumption has an odds ratio of 5.982 and obesity has an odds ratio of 4.945 , indicating that patients with uncontrolled hypertension who do not adhere to medication are 5.9 times more likely to suffer from uncontrolled hypertension than patients who do adhere to medication.

Following the researcher's assumption about the relationship between age and hypertension, the risk of hypertension increases with age because as a person ages, the regulation of calcium metabolism is disrupted, and increasing age will also cause the elasticity of the arteries to 
decrease and the heart to pump blood more vigorously, resulting in an increase in the production of many substances. Because of the lime that is circulated with the circulation, the blood gets denser and the blood pressure raises as a consequence. As a result of the natural rise in blood pressure that comes with age, the age group $>60$ years has the highest prevalence of hypertension.

An investigation of the relationship between gender and the frequency of uncontrolled hypertension in individuals who have regular checkups. After statistical analyses were performed, the findings revealed a significant test value of $0.620(>0.05)$ for the presence of gender differences in the incidence of hypertension. Therefore, it is concluded that there is no association between gender and the incidence of hypertension.

According to the findings of this research, gender is not a risk factor for hypertension; respondents who have hypertension, whether male or female, are at the same risk; the only thing that differentiates them is their way of life, which is the same for both men and women in this study.

According to the findings of the research, the family history variable $(\mathrm{p}=0.002$; Exp $(B)=$ 0.206; 95 percent confidence interval $[\mathrm{CI}]=0.075-0.566)$ was associated with a higher risk of breast cancer $(\mathrm{p}=0.002$; $\operatorname{Exp}(\beta)=0.206 ; 95$ percent $\mathrm{CI}=0.075-0.566)$. After performing logistic regression analysis, the family history variable acquired an Exp value (B) of 0.206, leading to the conclusion that respondents who have a family history of hypertension had a 0.206 times greater chance of developing the condition. A person who has a parent who has hypertension is twice as likely as someone who does not have a family history of hypertension to get hypertension themselves. This has something to do with the start of hypertension in the foreseeable future. 35 People who have close relatives who have a history of hypertension will have an increased chance of having the condition.

According to the study, if a person's parents have a history of hypertension, the likelihood that the individual has primary hypertension would be fairly high. This occurs as a result of the transmission of features via genetic inheritance. It is true that genetic variables play a significant influence in the development of hypertension. People with hypertension who have a family history of the condition are known to have a poor lifestyle, which is related with food. If someone follows a healthy eating plan, the likelihood that they will get hypertension is low.

According to the findings of the research, the obesity variable $(p=0.002 ; \operatorname{Exp}(\beta)=4.945 ; 95$ percent $C I=1.782-13,720$ ) was associated with a higher risk of heart disease. The findings of logistic regression analysis showed that the obesity variable had an Exp value (B) of 4.945, which led to the conclusion that respondents who are obese had a 4 times higher probability of developing hypertension than those who are not obese.

Obesity and high blood pressure are linked in some way. Increasing insulin levels in the blood are connected with increased body weight. This rise in insulin is coupled with salt and water retention, resulting in an increase in the amount of blood in the bloodstream. Blood volume will rise as a result of the increase in cardiac output, which will have an effect on rising blood pressure and the onset of hypertension. Higher plaque development in the arteries, as well as constriction of the arteries, are also connected with increased weight gain. When the arteries narrow, more blood flows through them, which increases the need for the heart to work harder to pump blood throughout the body. It is possible that this rise in desire will lead to an increase in blood pressure. Excessive weight and obesity are also known to produce sympathetic nerve hyperactivity, which leads in systemic vasoconstriction and an increase in heart rate, both of which contribute to elevated blood pressure levels. 
According to the calculations, there is no statistically significant relationship between smoking and the incidence of uncontrolled hypertension ( $p$-value $=1,000>0.05$ ). From the table, it can be seen that there are 110 respondents who do not smoke, with the majority of those who have uncontrolled hypertension being 55 people who do not smoke ( 74.3 percent).

The inhalation of toxic compounds such as nicotine and carbon monoxide, which enter the blood circulation and cause damage to the endothelial lining of the arteries, will result in the development of atherosclerosis and high blood pressure. Smoking also causes a rise in heart rate, which raises the demand for oxygen by the heart muscle tissue. The use of tobacco products by those with high blood pressure will significantly enhance the likelihood of arterial damage.

Cigarettes may raise the risk of blood vessel damage by depositing cholesterol in the coronary arteries, causing the heart to work harder as a result of the increased workload (Sandi et al., 2019). Smoking may cause long-term damage to the blood arteries, increasing the risk of developing illnesses such as stroke, heart disease, and heart attack; however, drinking enough of water and engaging in regular physical activity can help to mitigate this.

In the study, the findings showed that physical activity had an impact on the incidence of hypertension, with a significant value of 0.000 (p0.05) for the relationship. In the case group, there were 26 persons (35.1 percent) who reported engaging in regular physical exercise, whereas in the control group, there were 52 people ( 70.3 percent). The number of persons with uncontrolled hypertension in the case group with less physical activity was higher than the number of people in the case group, which was 48 people (64.9 percent).

Because it raises the likelihood of becoming overweight, a lack of physical exercise increases the chance of developing hypertension. People who are sedentary also have a greater heart rate, which means that the heart muscle needs to work more with each contraction than those who are active. The higher the amount of time and effort required by the heart muscle to pump, the greater the pressure imposed on the arteries. Exercise deprivation will raise the chance of obesity, and an increase in salt consumption will hasten the development of hypertension and other cardiovascular diseases (Norberg \& Danielsson, 2012). Because it raises the likelihood of becoming overweight, a lack of physical exercise increases the chance of developing hypertension. People who are sedentary also have a greater heart rate, which means that the heart muscle needs to work more with each contraction than those who are active. The higher the amount of time and effort required by the heart muscle to pump, the greater the pressure imposed on the arteries (Krousel-Wood et al., 2009).

According to the findings of the research, the variable salt intake $(p=0.000 ; \operatorname{Exp}(B)=0.081$; 95 percent confidence interval $[\mathrm{CI}]=0.029-0.225)$ was associated with the variable. It seems that there is a statistically significant association between salt intake and the occurrence of uncontrolled hypertension ( $\mathrm{p}$ value $=0.0000 .05$ ), according to the findings of the calculations. According to the findings of the study, the odds ratio (OR) is 4.127, indicating that excessive salt intake is associated with a fourfold increased risk of developing uncontrolled hypertension when compared to moderate salt consumption.

Salt produces an accumulation of fluid in the body, which raises the volume of blood and the pressure of the blood vessels. The average blood pressure in persons who ingested 3 grams of salt or less was shown to be lower, but those who consumed 7-8 grams of salt had greater average blood pressure. The recommended daily sodium intake is no more than 6 grams (or 3 teaspoons) per person. 
Sodium is a substance that the body need to function properly. The kidneys are responsible for maintaining the proper sodium levels in the body under normal conditions. High sodium consumption, on the other hand, might result in an increase in plasma volume, cardiac output, and blood pressure, among other things. Sodium causes the body to retain water at levels that are higher than the body's usual threshold, resulting in increased blood volume and high blood pressure, as well as other health problems. High sodium consumption produces adiposity cell hypertrophy in white fat tissue as a consequence of lipogenic processes. If this process is allowed to continue, it will result in the constriction of blood vessels by fat, which will result in a rise in blood pressure.

It seems that there is a statistically significant link between coffee drinking and the occurrence of uncontrolled hypertension (pvalue $=0.0100 .05$ ) based on the results of the calculations. According to the findings of the study, the odds ratio (OR) for uncontrolled hypertension is 2.276, which means that people who take coffee on a regular basis have a twofold increased chance of developing the condition compared to those who use coffee seldom. The risk of getting uncontrolled hypertension is higher in respondents who take 1-2 cups of coffee per day compared to respondents who do not consume coffee.

Central Aceh is one of Indonesia's top coffee growers, and the region's geographic position at an elevation of 1200 meters above sea level, with relatively low humidity and temperatures, makes it a desirable place for coffee production. Those who live in the Kebayakan sub-district of Central Aceh are a part of the indigenous traditions and culture of the people of Central Aceh, as are the majority of the inhabitants of Central Aceh Regency "Ngopi." In accordance with the findings of the research, it was determined that drinking coffee is a habit in the Central Aceh region, one that is practiced virtually every single day. Caffeine is found in coffee, and it has a competitive antagonistic impact on adenosine receptors in the body. Adenosine is a neuromodulator that has the ability to modulate a wide range of processes in the central nervous system. In turn, this has an effect on vasoconstriction and raises total peripheral resistance, both of which contribute to elevated blood pressure.

Coffee intake results in an increase in cardiac output as well as an increase in systolic pressure that is larger than the rise in diastolic pressure. In coffee, caffeine is the most abundant component, and it has an immediate impact on blood pressure, particularly in persons who have high blood pressure.

According to the findings of the research, the stress variable $(p=0.002 ; \operatorname{Exp}(\beta)=4.696 ; 95$ percent confidence interval $[\mathrm{CI}]=1.740-12.673$ ) was associated with a higher risk of heart disease. According to the findings of the logistic regression analysis, the stress variable had an Exp value (B) of 4.696, which means that respondents who feel stress had a 4 times increased probability of developing hypertension. Stress may cause a rise in blood pressure for a short period of time, after which the blood pressure will return to normal. Stress may be caused by unexpected occurrences, and the implications of chronic stress, which can lead to hypertension, have not yet been determined, according to the latest research. Stress is also extremely closely associated with high blood pressure. Stress is a condition that may lead to hypertension, and the association between stress and hypertension is assumed to be mediated by sympathetic nerve activity, with rising nerve activity leading to occasional increases in blood pressure (hypertension) (uncertainly). Stress that lasts for an extended period of time might result in chronically elevated blood pressure.

According to the findings of the research, the variable of drug consumption adherence $(\mathrm{p}=$ 0.000; $\operatorname{Exp}(ß)=5.982 ; 95$ percent confidence interval $[C I]=2.189-16.345)$ was shown to be significant. According to the findings of the logistic regression analysis, the stress variable had

Copyright $\odot$ 2021, International Journal Papier Advance and Scientific Review, Under the license CC BY-SA 4.0

DOI: $\underline{\text { https://doi.org/10.47667/ijpasr.v2i2.131 }}$ 
an Exp value ( $($ ) of 5.982, and it can be stated that respondents who do not adhere to medicine have a 5 times higher probability of suffering high blood pressure than those who do.

The findings of this study are consistent with prior research conducted by Rizki Yulia (2018), which found a link between the use of antihypertensive medications and the occurrence of uncontrolled hypertension $(\mathrm{p}=0.001, \mathrm{OR}=11,366)$ in the general population. compared to individuals who use antihypertensive medications on a regular basis

Patients who are taking antihypertensive medications are likely to continue taking them for the rest of their lives since the usage of antihypertensive medications is required to manage blood pressure in order to prevent and avoid problems. In the event that respondents do not adhere to the doctor's instructions on medication administration, the medication is not used; if you do not feel dizzy or have a headache, the medication is not taken (Purwanto, 2006).

\section{Conclusion}

Hypertensive patients are recommended to re-examine after 7-14 days to measure blood pressure, the average blood pressure measurement on the second examination is used as criteria for diagnosis and control of hypertension. The condition of high blood pressure that continues to cause the heart to work harder, so that this condition will result in damage to blood vessels, heart, kidneys, brain, and eyes.

\section{Suggestion}

It is expected to improve health services in terms of conducting health promotions about the dangers of hypertension in patients, recommending drug-taking assistance (PMO) for each patient and conducting health counseling for patients at risk of developing hypertension to prevent disease as early as possible.

\section{References}

Depkes, R. I. (2003). Kebijakan dan Strategi Nasional Pencegahan dan Penanggulangan Penyakit Tidak Menular. Departemen Kesehatan RI, Jakarta.

Dinkes. (2018). Profil kesehatan Aceh Tahun. Dinas Kesehatan Aceh

Krousel-Wood, M., Islam, T., Webber, L. S., Re, R., Morisky, D. E., \& Muntner, P. (2009). New medication adherence scale versus pharmacy fill rates in hypertensive seniors. The American journal of managed care, 15(1), 59.

Low, P. A. (Ed.). (2011). Primer on the autonomic nervous system. Academic Press.

Norberg, M., \& Danielsson, M. (2012). Overweight, cardiovascular diseases and diabetes: Health in Sweden: The national public health report 2012. Chapter 7. scandinavian Journal of public Health, 40(9_suppl), 135-163.

Notoatmodjo, S. (2010). Metodologi Penelitian Kesehatan, Rineka Cipta. Jakarta. Indonesia.

Sandi, M. R., Martini, S., Artanti, K. D., \& Widati, S. (2019). The description of modifiable risk factors in coronary heart disease at dr. Soetomo regional public hospital. Jurnal Berkala Epidemiologi, 7(2), 85-93.

Windarsih, A. D., \& Devianto, A. (2017). Hubungan antara stres dan tingkat sosial ekonomi terhadap hipertensi pada lansia. Jurnal Keperawatan Notokusumo, 5(1), 62-71. 